\title{
Performance of non-performing assets of Nagpur district Central Co-operative Bank
}

\author{
KOMAL R. BHASKAR, V. O. BONDHARE AND P. S. DESHMUKH
}

Received : 25.02.2016; Revised : 28.08.2016; Accepted : 15.09 .2016

\begin{abstract}
The research entitled, performance of non-performing assets of Nagpur District Central Co-operative Bank was carried and study is based on secondary data. The time series data relating to aspect of study was collected for the period from 1980-81 to 2010-11 from various annual reports of the bank. On the basis of analysis of data, NDCCB show good performance about number of branches, total member, paid up share capital, own reserved funds, total deposits and working capital, which were found to be positive and significant increased over a period of time. Number of branches of NDCCB, shows the positive growth rate of 18.69 per cent on overall period. Total member shows the increasing trends at the rate of 11.77 during study period. Paid up share capital found good and progressive lead of 2.55 per cent while that of own fund is 4.54 per cent. Total deposits are increasing day by day which reflect the faith of people on bank. It has the growth rate of 4.19 per cent during study period. Due to some financial corruption the bank has to face the loss large amount. To cover this loss bank has to regularly take loan from State Co-operative bank. Thus, the amount of borrowing shows the growth rate of 15.49 per cent during study period. Though there is much up and down in banking business, working capital of NDCCB shows the positive growth during study period. Loan disbursed i.e. loan and advances and SAO shows positive and significant growth, which reveals the contribution of bank on agricultural finance. Loan overdues, loan outstanding and NPA are increasing day by day which are the major problems of bank which leads to increasing the gross loss of bank. The growth rate of loan outstanding and loan overdues is found more in ST loan as compared to MT and LT loan. The NPA position of bank is also recovering as the passage of time. Thus, on overall basis, the gross loss increased by the NDCCB was found increasing trend from the year 2003 to 2010 (i.e. from Rs. 121.99 crore to Rs. 255.25 crore.) projected that the NDCCB was found in continuous loss in banking business.
\end{abstract}

KEY WORDS : Bank, Assets, Overdues, Loan

How to cite this paper : Bhaskar, Komal R., Bondhare, V.O. and Deshmukh, P.S. (2016). Performance of non-performing assets of Nagpur district Central Co-operative Bank. Internat. J. Com. \& Bus. Manage, 9(2) : 214-219, DOI: 10.15740/HAS/IJCBM/9.2/214-219.

MEMBERS OF THE RESEARCH FORUM

Correspondence to:

V.O.BONDHARE, Department of Agricultural Economics and Statistics, Post Graduate Institute, Dr. Panjabrao Deshmukh Krishi Vidyapeeth, AKOLA (M.S.) INDIA

Email: bondhare@gmail.com

\section{Authors' affiliations:}

KOMAL R. BHASKAR AND P.S. DESHMUKH, Department of Agricultural Economics and Statistics, Post Graduate Institute, Dr. Panjabrao Deshmukh Krishi Vidyapeeth, AKOLA (M.S.) INDIA 